UDC 94(477)"1917/1921":316.324.5

DOI 10.24919/2519-058X.21.246902

\title{
Vitaliy LOZOVYI
}

PhD hab. (History), Professor, chief consultant, National Institute for Strategic Studies, 7-A Pyrohova Street, Kyiv, Ukraine, postal code 01030 (lozovyi_v@ukr.net)

ORCID: 0000-0002-5057-2838

\section{Вімалій ЛОзОВИЙ}

доктор історичних наук, професор, головний консультант Наџіонального інституту стратегічних досліджень, вул. Пирогова, 7А, м. Київ, Україна, індекс 01054 (lozovyi_v@ukr.net)

Bibliographic Description of the Article: Lozovyi, V. (2021). Peasant Agrarianist Approaches and Practices of Resolving the Agrarian Issue during the Period of the Ukrainian Revolution of 1917 - 1921. Skhidnoievropeiskyi Istorychnyi Visnyk [East European Historical Bulletin], 21, 78-86. doi: 10.24919/2519-058X.21.246902

\section{PEASANT AGRARIANIST APPROACHES AND PRACTICES OF RESOLVING THE AGRARIAN ISSUE DURING THE PERIOD OF THE UKRAINIAN REVOLUTION OF $1917-1921^{1}$}

\begin{abstract}
The purpose of the article is to analyse the agrarianist by their content approaches and practices of solving the agrarian issue as a realization in practice of peasants 'hopes and ideas about their just future; to establish criteria for clarifying the agrarianist essence of practices for solving the agrarian issue, to determine the types of these practices; show the dynamics of changes in peasant agrarian approaches and practices under different forms of government during the Ukrainian Revolution of 1917 - 1921. The research methodology is a socio-cultural approach, which allows to explain how Ukrainian peasantry's mental guidelines, ways of seeing the solution of the agrarian issue affected the practices of solving the land issue and influenced the emergence of domestic agrarianism in 1917 - 1921. The scientific novelty consists in the following: it has been substantiated that during the revolutionary period of 1917 - 1921 there was a dynamic change in peasant agrarianist approaches and practices to solve the agrarian issue: from socialization policy based on the rejection of private ownership of land, free requisition of land from the owners and its transfer to the peasants for cultivation, to the inclination of the peasant community to receive land in private ownership for redemption to the state. The Conclusions. The following criteria for the agrarianist essence of approaches and practices for solving the agrarian issue during the revolution of 1917 - 1921 have been defined: if we consider the Bolshevik-Communist model, it is a denial of the nationalization of land and collective management on it; if we consider the bourgeois and capitalist model, it is a denial of large private ownership of land. Since in the grain growers' mentality the fundamental principle of land ownership or use was personal work on it, the main peasant agrarian approaches and practices to solve the agrarian question during the revolution of 1917 - 1921 were: 1 . preservation of small peasant private ownership of land; 2. transfer of land for life with the right of inheritance (which in the understanding of the peasantry was close to the right of private property in addition to the possibility of selling land). At the same time, a large part of the peasantry saw socialization as a certain transition period to private property, which had to go through the following stages: confiscation of land from landlords - its transfer to peasants for life - legitimization of peasant private ownership of this land.
\end{abstract}

Key words: peasantry, Ukrainian revolution of 1917 - 1921, agrarian issue, socialization, private property, land, Ukrainian agrarianism.

\footnotetext{
${ }^{1}$ The article contains the result sofre search conducted under a grant from the National Research Fund of Ukraine "Agrarianism: the Peasant-centric Phenomenon of the Ukrainian Revolution of 1917 - 1921" (registration number 2020.02/0120).
} 


\title{
СЕЛЯНСЬКІ АГРАРИСТСЬКІ ПІДХОДИ ТА ПРАКТИКИ ВИРІШЕННЯ АГРАРНОГО ПИТАННЯ У ПЕРІОД УКРАЇНСЬКОЇ РЕВОЛЮЦІї 1917 - 1921 рp.
}

\begin{abstract}
Анотація. Мета статті - проаналізувати аграристські за змістом підходи та практики розв'язання аграрного питання як реалізацію на практиці селянських сподівань і уявлень про їхнє справедливе майбутне; встановити критерї для з'ясування аграристської сутності практик із розв'язання аграрного питання, визначити різновиди ичих практик; показати динаміку зміни селянських аграристських підходів та практик за різних форм влади у період Украӥнської револючиї 1917 - 1921 рр. Методологією дослідження є сочіокультурний підхід, щуо дає можливість пояснити, як ментальні настанови, способи бачення розв 'язання аграрного питання українського селянства, позначилися на практиках розв'язання земельної проблеми та вплинули на появу вітчизняного аграризму в 1917 - 1921 рр. Наукова новизна полягає в обтрунтуванні того, щзо протягом револючійного періоду 1917-1921 рр. спостерігається динаміка зміни селянських аграристських підходів та практик розв'язання аграрної проблеми: від політики соціалізащії, базованої на відмові від приватної власності на землю, безоплатної реквізииії землі у власників та передачі ї̈ селянам у користування, до схиляння селянського загалу отримати землю у приватну власність за викуп державі. Висновки. Визначено такі критерії аграристської сутності підходів та практик із розв'язання аграрної проблеми в період революції 1917 - 1921 рр.: якщо брати більшовицько-комуністичну модель - це заперечення одержавлення землі та колективного господарювання на ній; якщо брати буржуазно-капіталістичну - це заперечення великої приватної власності на землю. Оскільки у хліборобській ментальності фундаментальною засадою володіння чи користування землею була особиста прачя на ній, основними селянськими аграристськими підходами та практиками із розв'язання аграрного питання у період революиії 1917 - 1921 рр. були: 1) збереження дрібної селянської приватної власності на землю; 2) передача землі у пожиттєве користування з правом успадкування (що у розумінні селянства було близьке до права приватної власності крім можливості землю продавати). Водночас значною частиною селянства соиіалізація вбачалася як певний перехідний період до приватної власності, яка мала пройти такі етапи: конфіскація землі у поміщиків - передача ї̈ селянам у довічне користування легітимізація селянської приватної власності на иъю землю.
\end{abstract}

Ключові слова: селянство, Украӥнська революиія 1917 - 1921 рр., аграрне питання, сочіалізація, приватна власність, земля, украӥнський аграризм.

The Problem Statement. Currently there are complex processes of land reform, implementation of the agricultural land market in our country. For the qualitative implementation of this reform in Ukraine, it is important not only to study the achievements of other countries, but also the powerful constructive experience that our country had during different periods of its history, including the revolutionary period of $1917-1921$.

Peasant and agrarian topics are a traditional segment of the domestic historiographical process. However, some issues have not been properly understood and developed. Therefore, among the important areas of further study of the history of the Ukrainian Revolution of 1917 - 1921 is to clarify the peasant agrarianist approaches and practices of solving the agrarian issue in the context of the socio-political model of the Ukrainian agrarianism.

The purpose of the article is to analyse the agrarianist by their content approaches and practices of solving the agrarian issue as a realization in practice of peasants' hopes and ideas about their just future; to establish criteria for clarifying the agrarianist essence of practices for solving the agrarian issue, to determine the types of these practices; to show the dynamics of changes in peasant agrarianist approaches and practices under different forms of government during the Ukrainian Revolution of 1917 - 1921.

The Analysis of Recent Researches. Domestic historians fruitfully research various aspects of the topic of agrarianism. In the collective monograph "Peasant-centric Dimension 
of the Socio-cultural Space of Ukraine during the Revolution of 1917 - 1921" low-studied issues of modern domestic and foreign historiography concerning the content of agriculture as a peasant-centric phenomenon of the Ukrainian revolution of 1917-1921 and the phenomenon of Central and Eastern European countries during the socio-political changes at the beginning of the twentieth century (Kornovenko, Telvak, et Lozovyi). Considering the subjective factor of the agrarian issue as one of the preconditions for the revolutionary events of $1917-1921$, S. Kornovenko concluded that a new active subject appeared on the forefront of history - the peasant-ideoman (Kornovenko, 2017, pp. 83-94). S. Kornovenko and N. Zemziulina studied the phenomenon of the Ukrainian agrarianism during the Ukrainian Revolution of 1917 1921 as a variant of Eastern European agrarianism, represented in the political programs of the Ukrainian national parties (Kornovenko, Zemziulina, 2019, pp. 14-20). S. Kornovenko and Y. Pasichna highlighted the intellectual foundations of the Ukrainian agrarianism of the revolutionary era in the views of V. Lypynsky (Kornovenko, Pasichna, 2021, pp. 107-121). The mentioned authors also found out the reasons for the emergence of Eastern European agrarianism, revealed the understanding of this concept, and along with other variants of agrarianism, singled out its Ukrainian variety (Kornovenko, Pasichna, 2019, pp. 24-30). S. Kornovenko and V. Telvak elucidated the origins and essence of agrarianism phenomenon in the countries of Central and South-Eastern Europe in the second half of the nineteenth the first third of the twentieth centuries and gave it its own definition (Kornovenko, Telvak, 2020, pp. 10-16). K. Galushko, having studied the "grain grower ideology" of V. Lypynsky, came to the conclusion that it is similar to Czechoslovak and Bulgarian agrarianisms, which represent an attempt to solve a set of socio-political issues of agrarian society, which suffered from the consequences of modernization (Halushko, 2000, pp. 164-200). However, the topic of peasant agrarianist approaches and practices of solving the agrarian issue in the context of clarifying the issue of formation and implementation of agrarian policy in the times of the Ukrainian Revolution of 1917 - 1921 is poorly developed and needs further research.

The Main Material Statement. The social structure of the Ukrainian society in the Dnieper region at the beginning of the twentieth century was dominated by the peasantry. A characteristic feature of agrarian relations in Ukraine was the presence of large landowners and peasant smallholdings, which caused social tension. About 19\% of Ukrainian peasants employed in agriculture were landless (Koval'ova, 2020, p. 116).

During the Ukrainian Revolution of 1917 - 1921, the peasantry became the subject of the political process and gave a strong voice to the solution of the most important issue for themselves - the land one. The socio-political model of the Ukrainian agrarianism was an alternative to the bourgeois capitalist and Bolshevik-communist models, the "third", "different" peasant way of society development (Kornovenko, Pasichna, 2019, pp. 24-30).

By peasant agrarianist approaches and practices of solving the agrarian issue, we mean the activity of the peasantry as a subject of socio-political process, which intends to solve the land issue according to its socio-economic interests and accordingly historically formed mental guidelines.

To understand the system of worldviews adequately and to some extent the ideological views of the peasantry, there should be considered the social values and ideals that it professed. Their views on property, especially land, can explain the phenomena of peasant behaviour. In the minds of peasants, the labour invested was valued above the right of private property legally enshrined in state (for peasants - lordly) laws (Ryl'skiy, 1903, p. 26); (Shanin, 1997, pp. 221-222). They claimed that the land "was not made by anyone, but created by God", the landowners seized the land and used the labour of the peasants 
(Kolysnychenko, 2006, p. 62). Therefore, the ownership of land by lords who do not work on it is not fair. The peasant worldview always meant that the land owned by the landowner for centuries was cultivated by "labour and sweat" of many generations of grain growers in the village and accumulated the whole set of their labour efforts. The peasants understood this material connection with their predecessors well and believed that the landlord's property was objectified by an additional product created by their labour and the labour of their greatgrandparents. This formed a strong belief that the landlord's wealth in truth and law should belong to the peasants and became a kind of peasant ideological justification for the need to expropriate land from the landlords and transfer it to working grain growers.

The consciousness of the peasantry determined the relations of property with the existing state institutions, with the relations of power. As the latter change, so must property relations. When, after the revolution of 1917, the old system collapsed, its components - the repressive power, the payment of taxes, and private ownership of land by landlords - ceased to be perceived as legitimate in the peasant consciousness.

In June of 1917, the First All-Ukrainian Peasants' Congress proclaimed the socialization of land and decided to seek the abolition of private ownership of land and its transfer without redemption to the Ukrainian land fund for further distribution among poor peasants (Ukrayinskyy natsionalno-vyzvolnyy rukh, 2003-34). 350). At the same time, a great public discussion began about the implementation of socialization. Some noted that the Ukrainian peasant "more or less the owner and he wanted" to have the right to own land. The others argued that socialization would ensure social justice in the countryside (Zemelne pytannya, 1917, p. 13).

At the initial stage of the revolution, when the SR propaganda was only gaining momentum, the peasants, according to ancient traditions, advocated family possession or use of land, but with mandatory indication of the principle of personal work. It should be noted that this circumstance, which, in our opinion, significantly influenced the attitude of the peasantry to the agrarian policy of different governments: the people's legal consciousness did not clearly distinguish between "property", "possession", "use" (Ukrayins'kaRSR v period hromadyans'koyi viyny, 1970, p. 16). For the peasants, all these concepts merged into one: to have a piece of land to ensure the existence of their family.

It is self-evident that a significant part of the Ukrainian peasants, having no experience of communal redistribution of land, preferred individual land tenure. However, later, under the pressure of political and socio-economic circumstances, their views evolved. This was prompted by the dynamics of revolutionary events after February of 1917, as a frantic propaganda campaign to popularize the idea of socialization was launched by the Ukrainian and Russian Socialist-Revolutionaries. The principles of agrarian transformation developed by them were approved by numerous peasant congresses of various levels and in fact legitimized in the minds of the general public the socialization of land as a manifestation of peasant aspirations. In the socialist press, at rallies and meetings, it was argued that socialization best reflected the interests of the peasants.

In addition, it should be noted the specifics of socio-economic differentiation of peasants. Within the community, there was a division on the basis of property between the rich and the poor, those who had land and those who sought to have it (Pervyy kamen (otkrytye volostnoho zemstva), 1917, p. 2). It is self-evident that these two strata of the peasant community had completely opposite orientations in resolving the agrarian issue. With the spread of democratization and the elimination of administrative pressure, the poor and middle peasants, being in the majority, could make decisions that became the decisions of the 
gathering, i.e., the whole community, and elect their representatives to various congresses, who voted for socialization.

Peasants-small landowners were afraid of socialization, because they believed that their land earned and bought by hard work could be taken away from them. In the newspaper "The Peasant Union" it was claimed: "The worst way to reconcile with the socialization of the land of those small landowners who work hard, without exploiting another, got a dozen acres of land and hold it with his teeth and hands. The greatest excitement and concern in the countryside over the land issue is in that part of the peasants who own rags of 10 - 25 dessiatyns of land..." (Pro zemlyu, 1917, p. 2).

The press noted the paradoxical situation in the countryside: the Ukrainian peasantsindividualists, i.e., owners, supported socialization, i.e., the abolition of private property, at their forums. This situation can be explained by the propaganda of the thesis that land ownership "brings poison into the life of the peasant". To buy land, the grain grower works hard and "does not see the light". When he knows that his children will already have land, that is, use it, it will bring peace and confidence in his soul that he will not die of starvation. The peasants were told that when there was no property, everyone would become "the master of the land, not a hireling, a half-worker or a worker for a sheaf” (Dumky pro zemlyu, 1917, p. 1). The latter statement had a special weight for the peasant mentality, so it sounded quite convincing.

A peculiar customary law justification for the return of land to the peasants was the dominant principle of "capture law" by the landlords in the peasant consciousness (CSAHAAU, f. 1412, d. 1, c. 8, p. 137). Accordingly, grain growers began to seize and divide privately owned land. Regional land administrations explained the agrarian movement by the fact that among peasants there was a strong notion that land that could not be cultivated by their own, personal labour should be "alienated for smallholders and landless" (CSAHAAU, f. 1412, d. 1, c. 46, p. 39).

In November of 1917, the Central Council, with its Third Universal, abolished land ownership and declared it an all-people property (CSAHAAU, f. 1115, d. 1, c. 4, p. 9). The main principle of the agrarian ideology of the Central Rada was the principle of personal labour inherent in peasant psychology, which was especially emphasized in the appeals and instructional documents of the Ukrainian authorities. Therefore, it was noted that the property is cancelled only by those who "do not work with their own hands". At the same time, landowners who have land areas of less than 50 dessiatyns, i.e., "in the size of the labour economy the Universal does not affect. Such labour property is not abolished, but remains as it was" until the Constituent Assembly (CSAHAAU, f. 1412, d. 1, c. 10, p. 28). Discussion in December of 1917 of the agrarian law of the UPR at a meeting of the Central Council, where representatives of the peasantry strongly opposed the proposed slightly lower labour rate of 40 dessiatyns (Ukrayinska Tsentralna Rada, 1997, pp. 26-27), shows that the rules left to the owners' land in $40-50$ acres peasants considered unjust.

Peasants were mostly in favour of the transfer of land to the hereditary, indefinite permanent use, although proposals were made to endow the land for 10 - 15 years (CSAHAAU, f. 1390, d. 1, c. 105, pp. 1-74). At the same time, almost everywhere the Ukrainian peasantry opposed joint land management (CSAHAAU, f. 1060, d. 1, c. 26, pp. 63-64).

Wealthy peasants and some middle peasants reacted to the agrarian reform of the Central Rada "with distrust, and even hostility", because they believed that its implementation could end in "economic catastrophe" (CSAHAAU, f. 1793, d. 1, c. 41, pp. 4, 107). In some regions, where there were a large number of wealthy peasants, they strongly opposed the implementation of land transformations. 
Uncertainty over land led to a significant reduction of sown areas in the spring of 1918. Grain growers did not know whether the land would remain in their use or would be redistributed within the community. The peasants sought certainty, and they showed a powerful instinct of the individual owner-landowner. Regional administrations reported to Kyiv that "uncertainty in land affairs is very harmful, although the peasantry has divided the land, does not know whether it will be their property or not..." and that many peasants came to the local authorities and said that the land should be given "at least less, but in property" (CSAHAAU, f. 1793, d. 1, c. 41, p. 93).

An interesting phenomenon was observed: evidence of the peasants' desire to transfer land to private ownership was contained in the reports of local authorities, but in fact did not appear in the decisions of provincial and county peasant congresses, which should express and record the agrarian aspirations of the peasantry and legitimize them in public consciousness for further implementation.

In our view, this paradoxical phenomenon testifies to the struggle between the immanent for peasant nature's desire for private property and the vision of social justice that was spread by SR propaganda. The ideal of social justice of the Russian community "to equalize all" was instilled on the Ukrainian soil. Not only smallholders and landless, but also the middle peasantry came under its influence, because in their understanding agrarian equality and the use of a few dessiatyns to ensure the biological existence of the family was a better socio-economic system than the existence of highly productive farms with large amounts of land. But, in this case, for the Ukrainian peasant, the question was not so much property (which he wanted) as justice. And the path to the second led through the abolition of the first, because the implementation of the requirement of justice led to the receipt of land, because its "surplus" from the owners had to be redistributed. And here it is necessary to state a typical peasant "trick", which determined the paradox of their behaviour: to get ownership of land, farmers supported the abolition of private property of landlords.

Here we should emphasize another circumstance: the regional difference in land tenure. If everything is clear with the Left Bank and the South, because there, at the gatherings, the peasants passed sentences on the transfer of land to communal use, then the issue arises about the Right Bank: did really the peasants who had land in individual possession, agree to socialization and want their property to become a national good? Paradoxically, the fact is that the peasants of the Right Bank almost did not declare at congresses and gatherings that they want the land to be privately owned. Thus, in our opinion, the Ukrainian peasants in regions with predominant individual land ownership recepted socialization only as a transitional stage - the stage of land expropriation from landlords, and further hoped to obtain land and through the mechanism of hereditary land use actually make it their private property. Thus, during the implementation of agrarian reform, the peasants of the Right Bank did not expect the abolition of property, but primarily the change of ownership, the ideological justification of which, as noted, was to be the principle of personal labour. And the community peasants, defending the transfer of privately owned lands to the rural community, with a ban on their sale, hoped that the distributed plots would be in their use almost forever.

Ethnographers who studied in the 20s of the twentieth century the phenomenon of seizure of landlord land by peasants during the revolution of 1917 - 1921 from the point of view of customary law wrote: "The revolution gave the peasants the opportunity to return the land actually, but the revolutionary method of seizure was not considered completely legal by the peasants. Honest feeling, legal consciousness was not completely reassured; the fact of seizure 
the peasants still felt, despite the decrees of the early days of the revolution on the right of all workers to land. Obviously, for a long time the traditions of the centuries that established the forms of land acquisition competed with the new norms, but the tradition, which gave certain habits, won, the element of crime felt in the seized lands through individuals and entire communities did not calm down until then until it is formalized by a resolution of the land department on the consolidation of land, giving it legal force" (Pratsi Komisiyi, 1928, pp. 307-308). That is, having seized the landlord's lands, which the peasants already considered their own, they still sought to legalize this fact.

Dissatisfaction of the owners you used the Ukrainian Democratic-Agricultural Party and held on April 7, 1918 in Lubny the grain grower congress of six povits of Poltava region. This representative assembly (more than 2,000 delegates) recognized the agrarian policy of the UPR government as destructive for the economy and demanded the restoration of private ownership of land. The Grain Growers' Forum proposed its principles of agrarian transformation: to leave a certain minimum of land to large farms, and to lease the rest to small farmers. Delegations with similar requirements came to Kyiv from different regions of Ukraine (Koval'ova, Kornovenko, Malynovs'kyy, Mykhaylyuk \& Morozov, 2007, p. 87). But this part of the rural population was not heard by the Central Rada and the UPR government.

With the coming of Hetman P. Skoropadsky to power, private ownership of the land was restored, which was ordered to be returned to the landlords. All statements of higher authorities emphasized that the main task of agricultural policy is to protect and strengthen small land ownership, "to meet the land needs of smallholder and landless grain growers" (Pravytelstvenne povidomlennya, 1918, p. 2.). It was declared that peasants would be able to increase their households by purchasing land purchased by the state from large landowners after the law established a certain size of land tenure.

The Hetman's government restored the rule of law and did not pay any attention to the fact that the psychology of the peasant masses had changed dramatically during the year of the revolution. The peasantry considered the previous agrarian division in their favour quite legitimate and just, and hoped for a favourable solution to the land issue. But the authorities actively pursued a policy of returning land and property to former landlords, which caused peasant riots and uprisings.

During the period of the Directory, which returned to the policy of land socialization, there is a clear tendency to change the agrarian approaches of the peasantry. The local authorities of the Ukrainian People's Republic noted a "change in the mood of the peasantry, which turned from socialization to the perpetual possession of land", and that the peasant "wants the land only in property" (CSAHAAU, f. 2192, d. 2, c. 6, p. 93). At its meetings and conventions, it increasingly expressed a desire to obtain land for possession and redemption to the state. Even if the peasants spoke out against private ownership of land, they still insisted that it should be in the individual hereditary use of members of a certain family (CSAHAAU, f. 1062, d. 1, c. 89, pp. 189, 213), i. e., it little different from private ownership. The peasants advocated such a land reform, under which land was to be given to each farm separately, and opposed the nationalization of land and collective management, which was promoted by the Bolsheviks and part of the SRs.

The peasants saw that during the whole period of agrarian transformations their status as land users was not determined. The land was given, then taken away. Then the pragmatic mind of the peasant began to incline to the purchase of land and the establishment of private ownership of it. The peasants claimed that they would be willing to pay the state for the land 
(CSAHAAU, f. 1062, d. 1, c. 89, p. 213). This would give the peasant the confidence of the landowner and would lead to the restoration of productive forces in the countryside. But the socialists in the UPR government adhered to their doctrines, ignoring the mood of the peasantry and the political expediency of changing agrarian policy to a more adequate socioeconomic situation in the countryside.

The Conclusions. Thus, the peasant agrarianist approaches and practices of solving the agrarian issue and the agrarian and revolutionary process in the countryside were influenced by the following important factors: 1 . historically formed mental guidelines of the peasantry to solve the land issue (denial of ownership of non-working elements and the belief that "the land belongs to God", and it must be owned by those who work on it"; the tendency of the peasantry to individual land ownership or land use); 2. dominance in the political space of socialist parties, which strongly spread their ideology (propaganda and agitation for the socialization of the land); 3. the dynamics of political change, the constant change of government, which saw the solution to the land issue in different ways and none of them was able to implement agrarian reform.

Since the socio-political model of the Ukrainian agrarianism was an alternative to the bourgeois capitalist and Bolshevik-communist models, the "third", "separate" peasant way of society development, we can define such criteria of agrarianist essence of approaches and practices to solve the agrarian issue during the revolution of 1917-1921: if we take the BolshevikCommunist model, it is a denial of the nationalization of land and collective management on it; if we take the bourgeois capitalist model, it is a denial of large private ownership of land.

In the grain grower mentality, the fundamental principle of owning or using land was personal work on it. The main peasant agrarian approaches and practices for solving the agrarian issue during the revolution of 1917 - 1921 were: 1 . preservation of small peasant private ownership of land; 2. transfer of land for life inheritance (which in the understanding of the peasantry was close to the right of private property except the possibility of selling land). At the same time, a large part of the peasantry saw socialization as a certain transition period to private property, which had to go through the following stages: confiscation of land from landlords - its transfer to peasants for life - legitimization of peasant private ownership of this land.

During the revolutionary period of 1917 - 1921 there was a dynamic change in peasant agrarianist approaches and practices of solving the agrarian issue from the policy of socialization based on the renunciation of private land ownership, free requisition of land from owners and its transfer to peasants for use, to persuading the peasant community to get land in private property for redemption to the state.

Acknowledgements. The author is sincerely grateful to all members of the editorial board for consultations provided during the preparation of the article for publishing.

Financing. The author did not receive financial support for the research, authorship and publication of this article.

\section{BIBLIOGRAPHY}

Dumky pro zemlyu. (1917). Dumky pro zemlyu [Thoughts about the Land]. Pryluts'ka dumka [Pryluky thought]. Pryluky, 7, 1. [in Ukrainian]

Halushko, K. (2000). "Khliborobska ideolohiia” V. Lypynskoho u systemi skhidnoievropeiskoho ahraryzmu ["Agricultural Ideology" V. Lypynsky in the system of Eastern European agrarianism]. Ukrainskyi istorychnyi zbirnyk, 2, 164-200. [in Ukrainian]

Kornovenko, S. \& Zemziulina, N. (2019). Ukrainian Agrarianism as an Option of Eastern European Agrarism in Political Programs of the Ukrainian National Parties of the Period of the Ukrainian Revolution. Ukrainskyi selianyn, 21, 14-20. [in English] 
Kornovenko, S. (2017). Sub'yektnyy skladnyk ahrarnoho pytannya yak odna z peredumov Ukrayins'koyi revolyutsiyi 1917 - 1921 rr. [Subjective Component of the Agrarian Issue as one of the Prerequisites of the Ukrainian Revolution of 1917 - 1921]. Ukrayins'kyy istorychnyy zhurnal, 4, 83-94. [in Ukrainian]

Kornovenko, S. \& Pasichna, Yu. (2021). Intellectual Bases of Ukrainian Agrarianism of the Revolutionary Epoch: Vyacheslav Lypynsky. Skhidnoievropeiskyi Istorychnyi Visnyk,19, 107-121. [in English]

Kornovenko, S. \& Pasichna, Yu. (2019) Eastern European Agrarianism. Ukrainian Intellectual Space in the Late 19th and Early 20th Centuries. Ukrayins 'kyyselyanyn, 22, 24-29. [in English]

Kornovenko, S. \& Tel'vak, V. (2020) Ahraryzm yak selyanotsentrychnyy fenomen krayin Tsentral'noyi ta Pivdenno-Skhidnoyi Yevropy druhoyi polovyny XIX - pershoyi tretyny XX st.: vytoky i sutnist' yavyshcha [Agrarianismas a Peasant-centric Phenomenon in Central and South-Eastern Europe in the Second Half of the Nineteenth - the First Third of the Twentieth Century: the Origins and Essence of the Phenomenon]. Ukrayins 'kyy selyanyn, 24, 10-16. [in Ukrainian]

Kornovenko, S., Telvak, V. \& Lozovyi, V. etc. (2021). Peasant-centric Dimension of the Sociocultural Space of Ukraine during the revolution of 1917 - 1921. Lviv-Torun: Liha-Pres, 128 p. [in English]

Kolysnychenko, D. (2006). Vserossyyskyy krest'yanskyy soyuz v 1905 - 1907 [All-Russian Peasants' Union in 1905 - 1907]. Moskva: Ynstytutrossyyskoyystoryy RAN, 313 p. [in Russian]

Koval'ova, N. (2020). Selyans'ka revolyutsiya v Naddnipryans'kiy Ukrayini (1902 - 1922). [PeasantrevolutionintheDnieperUkraine (1902-1922)]. Doctor's thesis. [inUkrainian]

Koval'ova, N., Kornovenko, S., Malynovs'kyy, B., Mykhaylyuk, O. \& Morozov, A. (2007). Ahrarna polityka v Ukrayini periodu natsional'no-demokratychnoyi revolyutsiyi (1917 - 1921). [Agrarian Policy in Ukraine during the National Democratic Revolution (1917 - 1921)]. Cherkasy: Ant, 280 p. [in Ukrainian]

Pervyy kamen' (otkrytye volostnoho zemstva). (1917). Pervyy kamen' (otkrytyevolostnohozemstva) [The First Stone (opening of the volost zemstvo)], Narodnoe slovo, 4, 2. [in Russian]

Pratsi Komisiyi. (1928). Pratsi Komisiyi dlya vyuchuvannya zvychayevoho prava Ukrayiny [Proceedings of the Commission for the Study of Customary Law of Ukraine]. Kyiv: WUAN, 3. [in Ukrainian]

Pravytel'stvenne povidomlennya. (1918). Pravytel'stvenne povidomlennya [Governmentreport]. Derzhavnyy vistnyk, 1, 2. [in Ukrainian]

Pro zemlyu. (1917). Pro zemlyu [Aboutland]. Selyans'ka spilka, 7, 2. [in Ukrainian]

Ryl'skiy, F. (1903). K izucheniyu ukrainskogo narodnogo mirovozzreniya [To the study of the Ukrainian folk world view]. Ekonomicheskiye otnosheniya, 1-53. [in Russian]

Shanin, T. (1997). Revolyutsiya kak moment istiny. Rossiya 1905 - 1907. 1917-1920. [Revolution as a Moment of Truth. Russia 1905 - 1907. 1917 - 1920]. Moskva: "Ves' mir", 555 p. [in Russian]

Tsentralnyi derzhavnyi arkhiv vyshchykh orhaniv vlady i upravlinnia Ukrainy [Central State Archive of the Highest Authorities and Administration of Ukraine - CSAHAAU]

Ukrayins'ka RSR v period hromadyans'koyi viyny. (1970). Ukrayins'ka RSR v period hromadyans'koyi viyny 1917 - 1920 [Ukrainian SSR during the Civil War of 1917 - 1920]. Vol. 3. Kyiv: Politvydav Ukrayiny, 463 p. [in Ukrainian]

Ukrayins'ka Tsentral'na Rada. (1997). Ukrayins'ka Tsentral'na Rada. Dokumenty i materialy. $U$ dvokh tomakh [Ukrainian Central Council. Documents and Materials. In two volumes]. (Ed. V. Verstyuk). Vol. 2. Kyiv. Naukovadumka, 424 p. [in Ukrainian]

Ukrayins'kyy natsional'no-vyzvol'nyy rukh. (2003). Ukrayins'kyy natsional'no-vyzvol'nyy rukh. Berezen'-lystopad 1917 roku. Dokumenty i materialy [Ukrainian National Liberation Movement. MarchNovember of 1917. Documents and Materials]. (Ed. V. Verstyuk). Kyiv. Vydavnytstvo imeni Oleny Telihy, 1024 p. [in Ukrainian]

Zemel'ne pytannya. (1917). Zemel'ne pytannya [Land Issue]. Podil's'ka volya, 12, 13. [in Ukrainian] The article was received February 11, 2020. Article recommended for publishing 24/11/2021. 